presence of ectopic gastric mucosa lining the tract, peptic ulceration can occur. Possible means of diagnosis are discussed and a plea is made for greater use of fibre-optic endoscopy and mesenteric angiography when appropriate. It is hoped, but as yet unproved, that the better use of modern diagnostic aids will lower the mortality of gastrointestinal haemorrhage.

\section{References}

Basu, R., Forshall, I. \& Rickham, P.P. (1960) Duplication of the alimentary tract. British Journal of Surgery, 47, 477.

BREWER, J.L. (1957) Congenital Anomalies of the VisceraTheir Embryological Basis, 1st edn, p. 68. Harvard University Press, Cambridge, Massachusetts.

BREWER, J.L. (1944) Diverticulae and duplications of the intestinal tract. Archives of Pathology, 38, 132.

Cotton, P.B., Rosenberg, M.T., Waldram, R.P.L. \& Axon, A.T.R. (1973) Early endoscopy of oesophagus, stomach and duodenal bulb in patients with haematemesis and melaena. British Medical Journal, 2, 505.

DoHn, K. \& Povlsen, D. (1971) Enterocystomas. Report of six cases. Acta chirurgica scandinavica, 102, 21.

Forshall, I. (1961) Duplication of the intestinal tract. Postgraduate Medical Journal, 37, 570.
Gross, R.E., Holcomb, G.W., JR \& Farber, S. (1952) Duplication of the alimentary tract. Pediatrics, 9, 449.

HoARe, A.M. (1975) Comparative study between endoscopy and radiology in acute upper gastrointestinal haemorrhage. British Medical Journal, 1, 27.

Holt, L.E. \& McIntosh, R. (1953) Pediatrics, 12th edn, p. 138. Appleton Century Croft, New York.

IRVING, J.D. \& NoRTHFIELD, T.C. (1976) Emergency arteriography in acute gastrointestinal bleeding. British Medical Journal, 1, 929.

KAY, A.W. (1962) Management of obscure alimentary bleeding. British Medical Journal, 1, 1709.

Mellish, R.W.P. \& KooP, E.E. (1961) Clinical manifestations of duplication of the bowel. Pediatrics, 27, 397.

Ravitch, M.M. (1953) Congenital abnormalities of the bowel. Pediatrics, 27, 397.

Reilly, H.F., WeismanN, R. \& Dyke, J.R. (1968) Duplication of the alimentary tract simulating carcinoma of the descending colon. Radiology, 90, 769.

RigG, B.N. (1974) Duplication of the alimentary tract Canadian Medical Association Journal, 110, 1124.

Rios, Dalenz, J.C., Kress, J.W. \& Montgomery, C.G (1965) Duplication of the small intestine with a perforation of a peptic ulcer in ectopic gastric mucosa. Archives of Surgery, 91, 863.

Sieber, W.K. (1956) Alimentary tract duplications. Archives of Surgery, 73, 383.

Stowens, D. (1959) Pediatric Pathology. 1st edn, p. 469 Williams and Williams Co., Baltimore.

\title{
Carcinoma of the lung presenting with a myeloproliferative disorder. A report of two patients
}

\author{
M. B. McIllmurray \\ M.B., M.R.C.P.
}

\author{
D. R. RYRIE \\ M.B., F.C.R.Path., M.R.C.P.
}

\author{
J. FLETCHER \\ M.D., F.R.C.P.
}

Departments of Medicine and Clinical Haematology, City Hospital, Hucknall Road, Nottingham

\begin{abstract}
Summary
A myeloproliferative disorder, similar to agnogenic myeloid metaplasia, has been described in patients with cancer. Two patients with carcinoma of the lung are described who presented with such a disorder but in whom there was no evidence of bone marrow fibrosis and in one of whom there was no evidence of bone marrow infiltration by tumour. The possible mechanism of this association is discussed.
\end{abstract}

\section{Introduction}

Bone marrow replacement by tumour is occasionally associated with the appearance of immature cells in the peripheral blood. Rarely, this is accompanied by marrow fibrosis and extramedullary haemopoiesis and simulates the clinical picture of agnogenic myeloid metaplasia. The explanation for this is unknown, for the changes are often absent in patients with extensive involvement and present in patients where involvement is slight.

This report describes two patients who presented with a disorder of blood cell production in association with a carcinoma of the lung and in both of whom post-mortem examination'showed evidence of haemopoiesis in the spleen but no evidence of bone marrow fibrosis, and in one of whom the bone marrow did not appear to be infiltrated by tumour.

\section{Case 1}

A 65-year-old smoker complained of lethargy, 
poor appetite, weight loss, unproductive cough and breathlessness of several months' duration. He was anaemic with smooth enlargement of both liver and spleen (12 $\mathrm{cm}$ below each costal margin) but no other abnormality was noted.

Blood indices were as follows: Haemoglobin $7.5 \mathrm{~g} / \mathrm{dl}$; MCH 29.6 pg; MCV $93 \mathrm{fl}$; neutrophils $3.3 \times 10^{9} / 1$; lymphocytes $1.6 \times 10^{9} / 1$; monocytes $2.6 \times 10^{\%} / 1$; metamyelocytes $0.5 \times 10^{2} / 1$; myelocytes $0.9 \times 10^{9} / 1$; platelets $45.0 \times 10^{\circ} / 1$. The blood film showed anisocytosis, poikilocytosis, normochromia, polychromasia and occasional siderocytes and nucleated red cells. The ESR was $80 \mathrm{~mm}$ in $1 \mathrm{hr}$. Coombs' test was negative. The bone marrow was markedly hypercellular with a myeloid-erythroid ratio of $9: 1$ and a disproportionate increase in promyelocytes. Megakaryocytes were normal. The bone biopsy contained large numbers of primitive haemopoietic cells but no foci of tumour cells and no increase in reticulin fibres. The leucocyte alkaline phosphatase score was zero but chromosome studies were normal. The liver and spleen confirmed the hepatosplenomegaly and there were no filling defects. The chest radiographs showed a mass lying behind and above the left hilum and another in the right lower paratracheal region. Lymphangiogram showed enlarged inguinal iliac and para-aortic lymph nodes with multiple filling defects in them. Sputum and bone marrow cultures for tubercle bacilli were negative. Other investigations included normal plasma levels of urea, electrolytes, bilirubin and liver enzymes. Alkaline phosphatase (liver origin) was 356 i.u./l (normal up to 190 i.u.).

The patient deteriorated slowly. The haematological changes and liver and spleen size remained the same whilst the lesions in his lungs and mediastinum increased in size. He died 6 months after presentation from an overwhelming chest infection. At post-mortem, a soft white necrotic oat cell tumour was found extending from the left lower lobe bronchus into the lung tissue, which also contained small multiple abscesses. Tumour deposits were also present in the left upper lobe, throughout the right lung in the left adrenal gland, brain, mediastinal and para-aortic lymph nodes and bone. The liver was enlarged ( $3160 \mathrm{~g})$ and contained numerous centrally necrotic metastases up to $2 \mathrm{~cm}$ in diameter, elsewhere the parenchyma was normal. The bone marrow was extensive and hypercellular but there was no increase in its reticulin or fibrous tissue content. The spleen was enlarged $(670 \mathrm{~g})$, without metastases and showed the characteristic histological appearance of myeloid metaplasia.

\section{Case 2}

A 78-year-old male smoker complained of increasing breathlessness and ankle swelling of 6 months duration. He was anaemic and there was slight ankle oedema, but no evidence of heart failure. Examination of the respiratory system and abdomen revealed no abnormality.

Blood indices were as follows: Haemoglobin 6.9 g/dl; MCH 35.3 pg; MCV $110 \mathrm{fl}$; neutrophils $3.3 \times 10^{9} / 1$; lymphocytes $1.8 \times 10^{9} / 1$; monocytes $0.8 \times$ $10^{9} / 1$; myeloblasts $0.8 \times 10^{9} / 1$; erythroblasts $11.7 \times$ $10^{9} / 1$; metamyelocytes $0.4 \times 10^{9} / 1$; myelocytes $0.8 \times$ $10^{9} / 1$; platelets $9 \cdot 1 \times 10^{9} / 1$. Coombs' test was negative. The bone marrow was hypercellular. Erythropoiesis was increased with a megaloblastic tendency and occasional cells contained double or distorted nuclei. The white cell precursors were mostly myeloblasts and promyelocytes, and thrombopoiesis was reduced. Serum vitamin $B_{12}$ was $>1400 \mathrm{ng} / \mathrm{l}$ and serum folate was $3.4 \mathrm{pg} / \mathrm{l}$. The chest radiographs showed a mass in the left upper lobe bronchus. Other investigations included normal plasma levels of urea, electrolytes, bilirubin and liver enzymes, and negative sputum cultures for tubercle bacilli.

The patient developed a chest infection soon after his admission to hospital and despite blood transfusion, physiotherapy and antibiotics he died. At post-mortem there was an undifferentiated squamous tumour, $4 \mathrm{~cm}$ in diameter arising from the left upper lobe. Acute inflammatory changes were seen in the trachea and bronchi together with bronchopneumonia in both lower lobes. There were no metastases. The bone marrow was hypercellular but there was no increase in reticulin or fibrous tissue content. The spleen was not enlarged (120 g) but showed the characteristic histological appearances of myeloid metaplasia.

\section{Discussion}

Agnogenic myeloid metaplasia is a chronic disorder characterized by a varying degree of fibrosis of the bone marrow, massive splenomegaly and a leuco-erythroblastic anaemia with marked red cell abnormalities, circulating normoblasts, immature granulocytes and atypical platelets (Dameshek and Gunz, 1964). It has been suggested that the marrow fibrosis is the initial event and is followed by the release of blood cell precursors into the circulation which colonize the liver and spleen (Chervenick, 1973). However, the concept has emerged of a return to the fetal condition of haemopoiesis with active pluripotential stem cells producing haemopoietic tissue in the liver and the spleen and fibrous tissue in the bone marrow (Ward and Block, 1971).

A disorder similar to agnogenic myeloid metaplasia is a rare, if well recognized concomitant of metastatic cancer (Kiely and Silverstein, 1969) and it has been assumed that the marrow fibrosis is a response to local irritation by the invading tumour. Both the patients had features to suggest 
such a disorder-the leuco-erythroblastic blood picture and histological evidence of haemopoiesis in the spleen, but the histological appearances of the bone marrow and biopsies were not those of myelofibrosis. The amount of bone marrow was excessive in both patients, despite extensive metastases in one of them (Case 1) and the absence of haemolysis or bleeding suggests that this cell proliferation was due to something other than simple compensatory hyperplasia. The monocytosis, present in both patients, could be a further manifestation of an abnormal marrow proliferation for, although blood monocyte counts are higher on average in patients with cancer, they rarely reach the level that was recorded in the first case (Barrett, 1970), and a monocytosis has been described in other myeloproliferative states (Maldonado and Hanlon, 1965).

Thus fibrosis of the bone marrow is not an essential feature of the myeloproliferative disturbance that has previously been described in patients with metastatic cancer. Furthermore, the failure to find tumour in the marrow of one of the present patients (Case 2) suggests that bone secondaries are not essential either. One explanation for this type of haematological complication of malignancy and of the myeloid metaplasia that has been described by others, is that some tumours elaborate a factor which stimulates fibroblastic, myeloid or erythroid activity to a varying degree and also interferes with the control of cell release from the bone marrow. This would not be surprising with an oat cell carcinoma whose capacity for synthetizing various polypeptides with physiological properties is well known. In addition this would support the suggestion that marrow fibrosis is not the initial event in the pathogenesis of agnogenic myeloid metaplasia.

\section{Acknowledgment}

We thank Professor M. J. S. Langman for his help in the preparation of this manuscript.

\section{References}

BARRetT, Col. O'NeILl, JR (1970) Monocytosis in malignant disease. Annals of Internal Medicine, 73, 991.

Chervenick, P. (1973) Increase in circulating stem cells in patients with myelofibrosis. Blood, 41, 67.

DAMESHEK, W. \& GunZ, F. (1964) Leukemia, Second Edn, Grune and Stratton, New York.

Kiely, J.M. \& Silverstein, M.N. (1969) Metastatic carcinoma simulating agnogenic myeloid metaplasia and myelofibrosis. Cancer. New York, Philadelphia, etc., 24, 1041.

Maldonado, J.E. \& Hanlon, D.G. (1965) Monocytosis: a current appraisal. Proceedings of Staff Meetings of the Mayo Clinic, 40, 248.

WARD, H.P. \& BLOCK, M.H. (1971) The natural history of agnogenic myeloid metaplasia and a critical evaluation of its relationship with the myeloproliferative syndrome. Medicine. Baltimore, 50, 357.

\title{
Papilloedema associated with respiratory failure
}

\author{
I. F. PYE \\ M.A., M.B., M.R.C.P. \\ R. L. BLANDFORD \\ M.B., M.R.C.P. \\ Department of Neurology, University Hospital of Wales, Heath Park, Cardiff
}

\begin{abstract}
Summary
A case of papilloedema secondary to respiratory failure is reported which caused considerable diagnostic difficulty and led to extensive neurological investigation. Neurological complaints of headache and visual impairment overshadowed respiratory symptoms and were associated with gross haemorrhagic papilloedema. The case is compared with previous reports and the pathogenesis of papilloedema in respiratory failure is reviewed briefly. The similarity between the pathogenesis of this condition and benign intracranial hypertension is discussed.
\end{abstract}

\section{Case history}

A 49-year-old housewife presented in January 1976 with a 4-year history of progressively severe right frontal headache exacerbated by coughing and lying down and which was frequently worse in the mornings. For 6 months vision had been indistinct, with difficulty in reading newsprint, and one momentary episode of absolute visual failure had occurred during December 1975. The patient's general health was good apart from long standing chest symptoms of wheezing and dyspnoea on hills and stairs, which she attributed to a chest deformity 